\title{
Association of Clostridium difficile with Antibiotic Associated Diarrhea among Hospitalized Children in Diyala-Iraq
}

\author{
Abdulrazak S. H. Hasan1, Rana S. M. Al-Zubaidi'2, Abbas A. Al-Duliami² \\ ${ }^{1}$ College of Medicine, Diyala University, Diyala, Iraq \\ ${ }^{2}$ College of Education, Diyala University, Diyala, Iraq \\ Email: razak1957@yahoo.com
}

How to cite this paper: Hasan, A.S.H., Al-Zubaidi, R.S.M. and Al-Duliami, A.A. (2019) Association of Clostridium difficile with Antibiotic Associated Diarrhea among Hospitalized Children in Diyala-Iraq. Journal of Biosciences and Medicines, 7, 64-73. https://doi.org/10.4236/jbm.2019.72006

Received: October 22, 2018

Accepted: January 30, 2019

Published: February 2, 2019

Copyright $\odot 2019$ by author(s) and Scientific Research Publishing Inc. This work is licensed under the Creative Commons Attribution International License (CC BY 4.0).

http://creativecommons.org/licenses/by/4.0/

\begin{abstract}
Background: Clostridium difficile infection (CDI) is an increasingly important cause of morbidity in hospitalized children. Absence of clinical suspicion and suboptimum laboratory diagnostic methods are behind the misdiagnosed infections. Objectives: To determine the association of Cl. difficle infection among hospitalized children suspected of having antibiotic associated diarrhea ( $\mathrm{AAD}$ ) plus detection of the bacterium's toxins $\mathrm{A}$ and $\mathrm{B}$ and the enzyme glutamate dehydrogenase (GDH). Patients and methods: This cross-sectional study was conducted in Al-Batool Hospital for Maternity and Children in Baquba City for the period from March 2017 to April 2018. Sixty stool samples were collected from children inpatients. The age range was 15 days up to one year. $41(68.3 \%)$ and $19(31.7 \%)$ were males and females respectively. Additionally, 20 healthy children were enrolled as control group. The age range was 50 days up to one year, $12(60 \%)$ and $8(40 \%)$ were males and females respectively. Special questionnaire was preconstructed for collection of demographic information. Isolation of $\mathrm{Cl}$. difficile was carried out on Colombia blood agar and tryptose sulfite cycloserine agar. Enzyme linked immunosorband assays were used for the detection of toxin A and B (CerTest-Biotec, Spain), and for the detection of glutamate dehydrogenase enzyme (CerTest-Biotec, Spain). Human privacy was respected by obtaining the parents' oral consent. Statistical analyses were done using SPSS Version 18 and P values less than 0.05 were considered significant. Results: The isolation rate of Cl. difficile form patients and healthy children was $11.7 \%$ and $5 \%$ respectively. The toxins detection rate among patients was $23.3 \%$, of these $35.7 \%$ for toxin A, and $64.3 \%$ for toxin A and B together. Neither of the patients' specimens was positive for toxin $\mathrm{B}$ alone, nor was healthy control positive for all toxins. The overall detection rate of GDH enzyme in study groups was $32.5 \%$,
\end{abstract}


with a significantly higher among patients as compared to control $(28.8 \%$ vs. $3.8 \%, \mathrm{P}=0.045)$. The isolation and detection rate of $C l$. difficile were increased as the time of the onset of diarrhea was increased. Other factors: age, sex, residence, and type of feeding were insignificantly affecting the isolation and detection rate of $\mathrm{Cl}$. difficile by different techniques. The third generation cephalosporines either singly or in combinations with each other or with another antibiotic were mostly associated with the higher rates of diarrhea. Conclusion: Cl. difficile infection is associated with about one third of antibiotic associated diarrhea among hospitalized children one year of age in Diyala province. CDI should be included in the routine differential diagnoses for hospitalized children presenting with AAD.

\section{Keywords}

Cl. difficile, Glutamate Dehydrogenase, Antibiotic Associated Diarrhea

\section{Introduction}

Clostridium difficile is an anaerobic, spore-forming, and toxin-producing bacillus that emerged as an important cause of antibiotic-associated diarrhea worldwide [1] [2] [3]. Cl. difficile colonizes the large intestine and releases two protein exotoxins (TcdA and TcdB) that cause colitis in susceptible persons. Infection is transmitted by spores that are resistant to heat, acid, and antibiotics. The spores are plentiful in health care facilities and are found in low levels in the environment and food supply, allowing for both nosocomial and community transmission particularly among children [4] [5]. Weakening of resistance by antibiotics or consumption of wrong antibiotics is the major risk factor for disease [6] [7]. Advanced age, antineoplastic chemotherapy, and severe underlying disease also contribute to susceptibility [8] [9] [10]. Furthermore, Cl. difficile ribotype was also found to be associated with severity of the clinical diarrhea [11]. The disease spectrum caused by $\mathrm{Cl}$. difficile infection ranges from mild, self-limited, illness to a severe, life-threatening colitis [12] [13]. The majorities of infants are colonized with $C$. difficile but are asymptomatic, possibly owing to the lack of toxin-binding receptors in the infant gut and as suggested by the common development of antibodies to Cl. difficile toxins without clinical infection [2] [14]. It has been documented that the due to absence of clinical suspicion and suboptimum laboratory diagnostic methods are behind the underestimation of Cl. difficile infection among hospitalized children [15] [16]. A wide variety of testing strategies for $\mathrm{Cl}$. difficile infection are currently employed either by enzyme immunoassay for toxins in stool or by DNA-based tests that identify the microbial toxin genes in unformed stool. Stool culture for Cl. difficile requires anaerobic culture and is not widely available. Enzyme immunoassay used to be the mainstay of testing for $C$. difficile infection, since it is rapid and easily performed [17] [18] [19]. 


\section{Patients and Methods}

This study is cross-sectional case control study. It was conducted in Al-Batool Hospital for Maternity and Children in Baquba City (the capital of Diyala province) for the period from March 2017 to April 2018. Sixty stool samples were collected from children in patients who were admitted and prescribed antibiotics for medical conditions other than diarrhea. One stool sample was collected for each patient in the same day as the clinical diarrhea was evident.The age range was 15 days up to one year. 41 (68.3\%) and 19 (31.7\%) were males and females respectively. Additionally, 20 healthy children were enrolled as control group. The age range was 50 days up to one year, $12(60 \%)$ and $8(40 \%)$ were males and females respectively. Special questionnaire was preconstructed for collection of demographic information, regarding age, sex, residence, date of admission and date of occurrence of diarrhea. Isolation of $\mathrm{Cl}$. difficile was carried out on Colombia blood agar and tryptose sulfite cycloserine agar and other selective media following alcohol shock [20]. Standard bacteriological and biochemical tests were used for the identification of $\mathrm{Cl}$. difficile. Enzyme linked immunosorband assay was employed for the detection of toxin A and B (CerTest-Biotec, Spain), and for the detection of glutamate dehydrogenase enzyme (CerTest-Biotec, Spain). Human privacy was respected by obtaining patients parent's oral consent. Statistical analyses were done using Statistical Package of Social Science (SPSS) version 18 and $\mathrm{P}$ values less than 0.05 was considered significant.

\section{Results}

The isolation rate of Cl. difficile form patients and healthy children was 11.7\% and $5 \%$ respectively. The toxins detection rate among patients was $23.3 \%$, of these $35.7 \%$ for toxin $\mathrm{A}$, and $64.3 \%$ for toxin $\mathrm{A}$ and $\mathrm{B}$ together. Neither of the patients' specimens was positive for toxin B alone, nor was healthy control positive for all toxins. The overall detection rate of GDH enzyme in study groups was $32.5 \%$, with a significantly higher among patients as compared to control (28.8\% vs. $3.8 \%, \mathrm{P}=0.045)$ (Table 1 ).

Table 2 showed that there was no significant effect of the type of feedings of patients on the detection rate of $\mathrm{Cl}$. difficile by any techniques.

Likewise, Table 3 revealed that there was no significant effect of the area of residence on the detection rate of $C l$. difficile by different techniques.

The duration is the time between the beginning of antibiotic treatment and the onset of diarrhea. Table 4 revealed that the detection rate of $C l$. difficile by all techniques used was insignificantly increased as the duration of treatment increased.

The detection rate of $C l$. difficile by different techniques was shown to be insignificantly higher among male compared to female, Table 5 .

Table 6 showed that neither the number of antibiotics/antibacterials nor the route of administration of these agents affects significantly the onset of diarrhea among children. 
Table 1. Detection rate of $C l$. difficile by toxins, enzyme and culture among study groups.

\begin{tabular}{|c|c|c|c|c|c|c|c|c|}
\hline \multirow{2}{*}{$\begin{array}{l}\text { Study } \\
\text { Groups }\end{array}$} & \multicolumn{2}{|c|}{ Toxin A } & \multicolumn{2}{|c|}{ Toxin A \& B } & \multicolumn{2}{|c|}{ Enzyme } & \multicolumn{2}{|c|}{ Culture } \\
\hline & $-(\%)$ & $+(\%)$ & $-(\%)$ & $+(\%)$ & $-(\%)$ & $+(\%)$ & $-(\%)$ & $+(\%)$ \\
\hline Patients & $46(57.5)$ & $14(17.5)$ & $51(63.8)$ & $9(11.3)$ & $37(46.3)$ & $23(28.8)$ & $53(66.3)$ & $7(8.8)$ \\
\hline Control & $20(100)$ & $0(00)$ & $20(100)$ & $0(00)$ & $17(21.3)$ & $3(3.8)$ & $19(23.8)$ & $1(1.3)$ \\
\hline Total & $66(82.5)$ & $14(17.5)$ & $71(88.8)$ & $9(11.3)$ & $54(67.5)$ & $26(32.5)$ & $72(90.0)$ & $8(10.0)$ \\
\hline$P$ value & \multicolumn{2}{|c|}{$0.036(\mathrm{~S})$} & \multicolumn{2}{|c|}{0.064 (NS) } & \multicolumn{2}{|c|}{$0.045(S)$} & \multicolumn{2}{|c|}{0.355 (NS) } \\
\hline
\end{tabular}

Table 2. Effect of feeding on the detection rate of $C l$. difficile by different techniques.

\begin{tabular}{|c|c|c|c|c|c|c|c|c|}
\hline \multirow{2}{*}{$\begin{array}{l}\text { Type of } \\
\text { feeding }\end{array}$} & \multicolumn{2}{|c|}{ Toxin A } & \multicolumn{2}{|c|}{ Toxin A \& B } & \multicolumn{2}{|c|}{ Enzyme } & \multicolumn{2}{|c|}{ Culture } \\
\hline & $-(\%)$ & $+(\%)$ & $-(\%)$ & $+(\%)$ & $-(\%)$ & $+(\%)$ & $-(\%)$ & $+(\%)$ \\
\hline Breast & $15(25)$ & $4(6.7)$ & $16(26.7)$ & $3(5.0)$ & $14(23.3)$ & $5(8.3)$ & $18(30.0)$ & $1(1.7)$ \\
\hline Artificial & $12(20)$ & $5(8.3)$ & $14(23.3)$ & $3(5.0)$ & $9(15.0)$ & $8(13.3)$ & $14(23.3)$ & $3(5.0)$ \\
\hline Mixed & $19(31)$ & $5(8.3)$ & $21(35.0)$ & $3(5.0)$ & $14(23.3)$ & $10(16.7)$ & $21(35.0)$ & $3(5.0)$ \\
\hline Total & $46(76.7)$ & $14(23.3)$ & $51(85.0)$ & $9(15.0)$ & $37(61.7)$ & $23(38.3)$ & $53(88.3)$ & 7 (11.7) \\
\hline$P$ value & \multicolumn{2}{|c|}{0.799 (NS) } & \multicolumn{2}{|c|}{0.905 (NS) } & \multicolumn{2}{|c|}{0.421 (NS) } & \multicolumn{2}{|c|}{0.463 (NS) } \\
\hline
\end{tabular}

Table 3. Effect of residence on the detection rate of $C l$. difficile by different techniques.

\begin{tabular}{|c|c|c|c|c|c|c|c|c|}
\hline \multirow{2}{*}{ Residence } & \multicolumn{2}{|c|}{ Toxin A } & \multicolumn{2}{|c|}{ Toxin A \& B } & \multicolumn{2}{|c|}{ Enzyme } & \multicolumn{2}{|c|}{ Culture } \\
\hline & $-(\%)$ & $+(\%)$ & $-(\%)$ & $+(\%)$ & $-(\%)$ & $+(\%)$ & $-(\%)$ & $+(\%)$ \\
\hline Rural & $28(46.7)$ & 7 (11.7) & $31(51.7)$ & $4(6.7)$ & $21(35.0)$ & $14(23.3)$ & $32(53.3)$ & $3(5.0)$ \\
\hline Urban & $18(30.0)$ & $7(11.7)$ & $20(33.3)$ & $5(8.3)$ & $16(26.7)$ & $9(15.0)$ & $21(35.0)$ & $4(6.7)$ \\
\hline Total & $46(76.7)$ & $14(23.3)$ & $52(85.0)$ & $9(15.0)$ & $37(61.7)$ & $23(38.3)$ & $53(88.3)$ & $7(11.7)$ \\
\hline$P$ value & \multicolumn{2}{|c|}{0.338 (NS) } & \multicolumn{2}{|c|}{0.289 (NS) } & \multicolumn{2}{|c|}{0.848 (NS) } & \multicolumn{2}{|c|}{0.314 (NS) } \\
\hline
\end{tabular}

Table 4. Effect of duration on the detection rate of $C l$. difficile by different techniques.

\begin{tabular}{ccccccccc}
\hline \multirow{2}{*}{$\begin{array}{c}\text { Duration } \\
(\text { Days })\end{array}$} & \multicolumn{2}{c}{ Toxin A } & \multicolumn{2}{c}{ Toxin A \& B } & \multicolumn{2}{c}{ Enzyme } & \multicolumn{2}{c}{ Culture } \\
\cline { 2 - 8 } & $-(\%)$ & $+(\%)$ & $-(\%)$ & $+(\%)$ & $-(\%)$ & $+(\%)$ & $-(\%)$ & $+(\%)$ \\
\hline $1-3$ & $15(25.0)$ & $6(10.0)$ & $19(31.3)$ & $2(3.3)$ & $14(23.3)$ & $7(11.7)$ & $18(30.0)$ & $3(5.0)$ \\
$4-6$ & $31(51.7)$ & $8(13.3)$ & $32(53.3)$ & $7(11.7)$ & $23(38.3)$ & $16(26.7)$ & $35(58.3)$ & $4(6.7)$ \\
Total & $46(76.7)$ & $14(23.3)$ & $51(85.0)$ & $9(15.0)$ & $37(61.7)$ & $23(38.3)$ & $53(88.3)$ & $7(11.7)$ \\
P value & $\mathbf{0 . 3 4 5}$ (NS) & $\mathbf{0 . 3 2 0}$ (NS) & $\mathbf{0 . 3 8 2}(\mathrm{NS})$ & $\mathbf{0 . 4 7 0}$ (NS) \\
\hline
\end{tabular}

Table 5. Effect of sex on the detection rate of Cl. difficile by different techniques.

\begin{tabular}{|c|c|c|c|c|c|c|c|c|}
\hline \multirow{2}{*}{ Sex } & \multicolumn{2}{|c|}{ Toxin A } & \multicolumn{2}{|c|}{ Toxin A \& B } & \multicolumn{2}{|c|}{ Enzyme } & \multicolumn{2}{|c|}{ Culture } \\
\hline & $-(\%)$ & $+(\%)$ & $-(\%)$ & $+(\%)$ & $-(\%)$ & $+(\%)$ & $-(\%)$ & $+(\%)$ \\
\hline Male & $33(55.0)$ & $8(13.3)$ & $35(58.3)$ & $6(10.0)$ & $23(38.3)$ & $18(30.0)$ & $37(61.7)$ & $4(6.7)$ \\
\hline Female & $13(21.7)$ & $6(10.0)$ & $16(26.7)$ & $3(5.0)$ & $14(23.3)$ & $5(8.3)$ & $16(26.7)$ & $3(5.0)$ \\
\hline Total & $46(76.6)$ & $14(23.3)$ & $51(85.0)$ & $9(15.0)$ & $37(61.7)$ & $23(38.3)$ & $53(88.3)$ & $7(11.7)$ \\
\hline$P$ value & \multicolumn{2}{|c|}{0.239 (NS) } & \multicolumn{2}{|c|}{0.593 (NS) } & \multicolumn{2}{|c|}{0.154 (NS) } & \multicolumn{2}{|c|}{0.389 (NS) } \\
\hline
\end{tabular}


Table 6. Effect of the number and route of antibiotics on the onset of diarrhea.

\begin{tabular}{ccccccc}
\hline \multirow{2}{*}{$\begin{array}{c}\text { Onset of diarrhea } \\
\text { (Days) }\end{array}$} & \multicolumn{3}{c}{ No. antibiotics } & \multicolumn{3}{c}{ Route of administration } \\
\cline { 2 - 7 } & Single & Double & Triple & Syrup & Injection & Mixed \\
\hline $1-3$ & $12(20.0)$ & $9(15.0)$ & $0(00)$ & $2(3.3)$ & $18(30.0)$ & $1(1.7)$ \\
$4-6$ & $24(40.0)$ & $12(20.0)$ & $3(5.0)$ & $1(1.7)$ & $36(60.0)$ & $2(3.3)$ \\
Total & $36(60.0)$ & $21(35.0)$ & $3(5.0)$ & $3(5.0)$ & $54(90.0)$ & $3(5.0)$ \\
P value & & $\mathbf{0 . 3 5 5 ( N S )}$ & & & $0.793(\mathrm{NS})$ & \\
\hline
\end{tabular}

Different antibiotics and antibacterial agents either singly or in combinations were used in the treatment of patients, These include Cephalosporines, B-lactams, Aminoglucosides, Wall teichoic acid inhibitors (WTAI). It was appeared that there is insignificant association between the type of antibiotic/antibacterial used and the onset of diarrhea in pediatric patients $(P=0.613)$. Generally, third generation cephalosporines (Cefotaxime and Cefpodoxmine) either singly or in combinations (with each other or with another antibiotic/antibacterial) were associated with the higher rates of diarrhea, Table 7.

\section{Discussion}

Antibiotic-associated diarrhea refers to passing loose, watery stools three or more times a day results from an imbalance in the colonic microbiota caused by antibiotic/antibacterial therapy [2] [21]. Cl. difficile, continues to be the most common identifiable pathogen accounting for $10 \%$ to $20 \%$ of AAD cases [4] [22] [23]. During the past decade, the epidemiology of Cl. difficile infection has changed, including a rise in the rate and severity of infection related to the emergence of a hypervirulent strain as well as an increase in disease among outpatients in community settings [12] [24]. Moreover, Cl. difficile is increasingly recognized as an important pathogen among children whom frequently experience more rapid onset of symptoms, a shorter duration of disease and fewer CDI complications [25] [26].

Clinically, AAD is a common medical problem in our hospitals, but unfortunately, we have neither an estimate of the rate of AAD among hospitalized patients nor the causative agents behind that. So, for the best of our knowledge this is the first study highlights the role of $C l$. difficile among pediatric patients. To figure out which is the most efficient, four techniques were employed in this study for the detection of $\mathrm{Cl}$. difficile in stool specimens of hospitalized children who were admitted for aliments other than diarrhea but they developed diarrhea after antibiotic/antibacterial therapy. Of note, most laboratories still use diagnostic tests with suboptimal sensitivity, hence a significant proportion of CDIs remain undiagnosed [15] [22].

According to culture on differential and selective media, the results showed that the rate of stool positive culture was insignificantly higher among patients as compared to controls ( $8.8 \%$ vs. $1.3 \%, \mathrm{P}=0.38)$. Higher isolation rates were reported by studies from different countries [19] [27]. Of note, it has been found 
Table 7. Association between the type of antibiotic and the time of onset of diarrhea.

\begin{tabular}{cccc}
\hline \multirow{2}{*}{ Type of antibiotic } & \multicolumn{2}{c}{ Onset of diarrhea (Days) } & \multirow{2}{*}{ Total (\%) } \\
\cline { 2 - 3 } & $1-3($ No. \%) & $4-6($ No. \%) & \\
\hline Cephalosporines & $4(6.7)$ & $20(33.3)$ & $24(40.0)$ \\
B-lactams & $5(8.3)$ & $3(5.0)$ & $8(13.3)$ \\
Aminoglucosides & $1(1.7)$ & $2(3.3)$ & $3(5.0)$ \\
Wall teichoic acid inhibitor (WTAI) & $2(3.3)$ & $1(1.7)$ & $3(5.0)$ \\
Cephalosporine + B-lactam & $6(10.0)$ & $7(11.7)$ & $13(21.7)$ \\
Cephalosporines + WTAI & $1(1.7)$ & $4(6.7)$ & $5(8.3)$ \\
Cephalosporine + B-lactam + WTAI & $2(3.3)$ & $2(3.3)$ & $4(6.7)$ \\
Total & $21(30.0)$ & $39(85.5)$ & $60(100.0)$ \\
\hline
\end{tabular}

that the type of culture media employed, the type of dominated strain, and the technique used affects the isolation rate of Cl. difficile from stool samples [20] [28] [29].

Through detection of enzyme glutamate dehydrogenase, the present results revealed that the detection rate among pediatric patients was significantly higher than that of controls $(28.8 \%$ vs $3.8 \%, \mathrm{P}=0.045)$. Different studies have reported different detection rates [3] [27] [28]. It has been reported that using GDH antigen as the screening and toxin $\mathrm{A}$ and $\mathrm{B}$ as confirmatory test for C. difficile, $85 \%$ of stool specimens were diagnosed [30]. Confidently, it is worth to mention that through a simple comparison among the 4 techniques employed, the detection of glutamate dehydrogenase enzyme was found to be the most efficient one as it detect $28.8 \%$ of the cases.

Detection of toxin A, toxin B, and both $\mathrm{A}$ and $\mathrm{B}$ of Cl. difficile were other techniques used in this study. Unfortunately toxin B was not detected in both patients and control. However, the detection rate of toxin A was significantly higher among patients compared to controls $(P=0.036)$. Similarly, the detection rate of toxin $\mathrm{A} / \mathrm{B}$ was higher in patients than in controls, but the difference was failed to reach the levels of statistical significance $(P=0.064)$. It was well documented that there were important regional differences in the toxinotype and ribotype of Cl. difficile, risk factors and consequently its disease severity [8] [9] [31]. Our results are consistent with previous studies [32] [33]. Therefore, based on their sensitivity and specificity enzyme immunoassays for the detection of $C$. difficile toxins A and B directly in fecal specimens or in toxigenic cultures were widely acceptable tests [27] [31].

Regarding the demographic factors, there was no significant effect of residence and type of feeding on the detection rate of $\mathrm{Cl}$. difficile by all four techniques. However, the results revealed that there was insignificant increase in detection rate of the four techniques among male compared to female. Higher rate of CDI among male patients was also reported by [33]. Conversely, the incidence was estimated to be higher among females in the USA [4]. Moreover, the results 
also revealed that the detection rate of $C l$. difficile by all four techniques was insignificantly increased as the onset of diarrhea delayed (duration of antibiotic/antibacterial prolonged). Almost all studies conducted in this field are agreed that recent antibiotic exposure and hospitalization remain key risk factors for CDI in the hospitalized pediatric patients [1] [6] [34]. The present results also found that neither the number of antibiotics/antibacterial prescribed nor the route of administration was significantly affected the onset of diarrhea. However, the third generation cephalosporines (Cefotaxime and Cefpodoxmine) either singly or in combinations (with each other or with another antibiotic/antibacterial) were associated with the higher rates of diarrhea. Similar results was reported by other workers suggesting that revised antibiotic guidelines was associated with a significant stepwise reduction in the use of cephalosporins and fluoroquinolones and a significant decrease in the incidence of CDI [2] [35] [36]. Furthermore, it has been reported that reduction in the use of high-risk antibiotics was associated with a significant change in the incidence trend of CDI [37] [38].

\section{Conclusion}

It can be concluded that $C l$. difficile infection is associated with about one third of antibiotic associated diarrhea among one-year-old hospitalized children in Diyala province. Asserting that the present study obtained an accurate picture of the real dimensions of the CDI, a more systematic use of an adequate and universal diagnostic strategy was requested plus the implementation of continuous monitoring of CDI through surveillance programme [16] [21]. The study recommends that CDI should be included in the routine differential diagnoses for hospitalized children presenting with $\mathrm{AAD}$ in health care settings.

\section{Conflicts of Interest}

The authors declare no conflicts of interest regarding the publication of this paper.

\section{References}

[1] Samady, W., Pong, A. and Fisher, E. (2014) Risk Factors for the Development of Clostridium difficile Infection in Hospitalized Children. Current Opinion in Pediatrics, 26, 568-572. https://doi.org/10.1097/MOP.0000000000000126

[2] Leffler, D.A. and Lamont, J.T. (2015) Clostridium difficile Infection. New England Journal of Medicine, 372, 1539-1548. https://doi.org/10.1056/NEJMra1403772

[3] Krutova, M., Kinross, P., Barbut, F., Hajdu, A., Wilcox, M.H. and Kuijper, E.J. (2018) Survey Contributors. How to: Surveillance of Clostridium difficile Infections. Clinical Microbiology and Infection, 24, 469-475. https://doi.org/10.1016/j.cmi.2017.12.008

[4] Lessa, F.C., Mu, Y., Bamberg, W.M., Beldavs, Z.G., Dunn, J.R., Farley, M.M., Holzbauer, S.M., Meek, J.I., Phipps, E.C., Wilson, L.E., Winston, L.G., Cohen, J.A., Limbago, B.M., Fridkin, S.K., Gerding, D.N. and McDonald, L.C. (2015) Burden of Clostridium difficile Infection in the United States. New England Journal of Medicine, 372, 825-834. https://doi.org/10.1056/NEJMoa1408913 
[5] Chilton, C.H., Pickering, D.S. and Freeman, J. (2018) Microbiologic Factors Affecting Clostridium difficile Recurrence. Clinical Microbiology and Infection, 24, 476-482. https://doi.org/10.1016/j.cmi.2017.11.017

[6] Hopkins, C.J. (2014) Inpatient Antibiotic Consumption in a Regional Secondary Hospital in New Zealand. Internal Medicine Journal, 44, 185-190. https://doi.org/10.1111/imj.12345

[7] Ianiro, G., Tilg, H. and Gasbarrini, A. (2016) Antibiotics as Deep Modulators of Gut Microbiota: Between Good and Evil. Gut, 65, 1906-1915. https://doi.org/10.1136/gutjnl-2016-312297

[8] Pant, C., Anderson, M.P., Deshpande, A., Altaf, M.A., Grunow, J.E., Atreja, A. and Sferra, T.J. (2013) Health Care Burden of Clostridium difficile Infection in Hospitalized Children with Inflammatory Bowel Disease. Inflammatory Bowel Diseases, 19, 1080-1085. https://doi.org/10.1097/MIB.0b013e3182807563

[9] Hourigan, S.K., Oliva-Hemker, M. and Hutfless, S. (2014) The Prevalence of Clostridium difficile Infection in Pediatric and Adult Patients with Inflammatory Bowel Disease. Digestive Diseases and Sciences, 59, 2222-2227.

https://doi.org/10.1007/s10620-014-3169-4

[10] van Beurden, Y.H., Nezami, S., Mulder, C.J.J. and Vandenbroucke-Grauls, C.M.J.E. (2018) Host Factors Are More Important in Predicting Recurrent Clostridium difficile Infection than Ribotype and Use of Antibiotics. Clinical Microbiology and Infection, 24, 85.e1-85.e4. https://doi.org/10.1016/j.cmi.2017.07.025

[11] Silva, R.O., Rupnik, M., Diniz, A.N., Vilela, E.G. and Lobato, F.C. (2015) Clostridium difficile Ribotypes in Humans and Animals in Brazil. Memórias do Instituto Oswaldo Cruz, 110, 1062-1065. https://doi.org/10.1590/0074-02760150294

[12] Kachrimanidou, M. and Malisiovas, N. (2011) Clostridium difficile Infection: A Comprehensive Review. Critical Reviews in Microbiology, 37, 178-187. https://doi.org/10.3109/1040841X.2011.556598

[13] Elliott, B., Androga, G.O., Knight, D.R. and Riley, T.V. (2017) Clostridium difficile Infection: Evolution, Phylogeny and Molecular Epidemiology. Infection, Genetics and Evolution, 49, 1-11. https://doi.org/10.1016/j.meegid.2016.12.018

[14] Taori, S.K., Wroe, A., Hardie, A., Gibb, A.P. and Poxton, I.R. (2014) A Prospective Study of Community-Associated Clostridium difficile Infections: The Role of Antibiotics and Co-Infections. Journal of Infection, 69, 134-144. https://doi.org/10.1016/j.jinf.2014.04.002

[15] Davies, K.A., Longshaw, C.M., Davis, G.L., Bouza, E., Barbut, F., Barna, Z., Delmee, M., Fitzpatrick, F., Ivanova, K., Kuijper, E., Macovei, I., Mentula, S., Mastrantonio, P., von Müller, L., Oleastro, M., Petinaki, E., Pituch, H., Noren, T., Novakova, E., Nyc, O., Rupnik, M., Schmid, D. and Wilcox, M.H. (2014) Underdiagnosis of Clostridium difficile across Europe: The European, Multicentre, Prospective, Biannual, Point-Prevalence Study of Clostridium difficile Infection in Hospitalised Patients with Diarrhoea (EUCLID). The Lancet Infectious Diseases, 14, 1208-1219. https://doi.org/10.1016/S1473-3099(14)70991-0

[16] Kola, A., Wiuff, C., Akerlund, T., van Benthem, B.H., Coignard, B., Lyytikäinen, O., Weitzel-Kage, D., Suetens, C., Wilcox, M.H., Kuijper, E.J., Gastmeier, P. and Members of ECDIS-Net (2016) Survey of Clostridium difficile Infection Surveillance Systems in Europe, 2011. Euro Surveillance, 21, 21-29. https://doi.org/10.2807/1560-7917.ES.2016.21.29.30291

[17] Koo, H.L., Van, J.N., Zhao, M., et al. (2014) Real Time Polymerase Chain Reaction Detection of Asymptomatic Clostridium difficile Colonization and Rising C. diffi- 
cile-Associated Disease Rates. Infection Control \& Hospital Epidemiology, 35, 667-673. https://doi.org/10.1086/676433

[18] Spigaglia, P., Barbanti, F., Castagnola, E., Diana, M.C., Pescetto, L. and Bandettini, R. (2017) Clostridium difficile Causing Pediatric Infections: New Findings from a Hospital-Based Study in Italy. Anaerobe, 48, 262-268.

https://doi.org/10.1016/j.anaerobe.2017.10.008

[19] Gateau, C., Couturier, J., Coia, J. and Barbut, F. (2018) How to: Diagnose Infection Caused by Clostridium difficile. Clinical Microbiology and Infection, 24, 463-468. https://doi.org/10.1016/j.cmi.2017.12.005

[20] Luna, R.A., Boyanton, B.L., Mehta, S., Courtney, E.M., Webb, C.R., Revell, P.A. and Versalovic, J. (2011) Rapid Stool-Based Diagnosis of Clostridium difficile Infection by Real-Time PCR in a Children's Hospital. Journal of Clinical Microbiology, 49, 851-857. https://doi.org/10.1128/JCM.01983-10

[21] Zhou, F.F., Wu, S., Klena, J.D. and Huang, H.H. (2014) Clinical Characteristics of Clostridium difficile Infection in Hospitalized Patients with Antibiotic-Associated Diarrhea in a University Hospital in China. European Journal of Clinical Microbiology \& Infectious Diseases, 33, 1773-1779. https://doi.org/10.1007/s10096-014-2132-9

[22] Tattevin, P., Buffet-Bataillon, S., Donnio, P.Y., Revest, M. and Michelet, C. (2013) Clostridium difficile Infections: Do We Know the Real Dimensions of the Problem? International Journal of Antimicrobial Agents, 42, S36-S40. https://doi.org/10.1016/j.ijantimicag.2013.04.009

[23] Wiedel, N., Gilbert, J., Baloun, B. and Nelson, C. (2016) Clostridium difficile Associated Diarrhea. South Dakota Medicine, 69, 124-127.

[24] Shin, J.H., Chaves-Olarte. E. and Warren, C.A. (2016) Clostridium difficile Infection. In: Scheld, W., Hughes, J. and Whitley, R., Eds., Emerging Infections 10, ASM Press, Washington, DC. https://doi.org/10.1128/microbiolspec.EI10-0007-2015

[25] Jonathan, D., Crews, J.D., Koo, H.L., Jiang, Z., Starke, J.R. and DuPont, H.L. (2014) A Hospital-Based Study of the Clinical Characteristics of Clostridium difficile Infection in Children. Pediatric Infectious Disease Journal, 33, 924-928. https://doi.org/10.1097/INF.0000000000000338

[26] McFarland, L.V., Ozen, M., Dinleyici, E.C. and Goh, S. (2016) Comparison of Pediatric and Adult Antibiotic-Associated Diarrhea and Clostridium difficile Infections. World Journal of Gastroenterology, 22, 3078-3104. https://doi.org/10.3748/wjg.v22.i11.3078

[27] Russello, G., Russo, A., Sisto, F., Scaltrito, M.M. and Farina, C. (2012) Laboratory Diagnosis of Clostridium difficile Associated Diarrhoea and Molecular Characterization of Clinical Isolates. New Microbiologica, 35, 307-316.

[28] Rene, P., Frenette, C.P., Schiller, I., Dendukuri, N., Brassard, P, Fenn, S. and Loo, V.G. (2012) Comparison of Eight Commercial Enzyme Immunoassays for the Detection of Clostridium difficile from Stool Samples and Effect of Strain Type. Diagnostic Microbiology and Infectious Disease, 73, 94-96. https://doi.org/10.1016/j.diagmicrobio.2012.01.005

[29] Mattner, F., Winterfeld, I. and Mattner, L. (2012) Diagnosing Toxigenic Clostridium difficile: New Confidence Bounds Show Culturing Increases Sensitivity of the Toxin A/B Enzyme Immunoassay and Refute Gold Standards. Scandinavian Journal of Infectious Diseases, 44, 578-585. https://doi.org/10.3109/00365548.2012.655772

[30] Alfa, M.J. and Sepehri, S. (2013) Combination of Culture, Antigen and Toxin De- 
tection, and Cytotoxin Neutralization Assay for Optimal Clostridium difficile Diagnostic Testing. Canadian Journal of Infectious Diseases and Medical Microbiology, 24, 89-92. https://doi.org/10.1155/2013/934945

[31] Krutova, M., Matejkova, J., Zajac, M., Hubacek, P. and Nyc, O. (2014) Diagnosis of Clostridium difficile Infections: Comparative Study of Two Immuno Enzyme Assays with Confirmation by PCR and Culture Followed by PCR Ribotyping. Epidemiologie, Mikrobiologie, Imunologie, 63, 99-102.

[32] Loo, V.G., Bourgault, A.M., Poirier, L., Lamothe, F., Michaud, S., Turgeon, N., Toye, B., Beaudoin, A., Frost, E.H., Gilca, R., Brassard, P., Dendukuri, N., Beliveau, C., Oughton, M., Brukner, I. and Dascal, A. (2011) Host and Pathogen Factors for Clostridium difficile Infection and Colonization. New England Journal of Medicine, 365, 1693-1703. https://doi.org/10.1056/NEJMoa1012413

[33] Kaneria, M.V. and Paul, S. (2012) Incidence of Clostridium difficile Associated Diarrhoea in a Tertiary Care Hospital. Journal of the Association of Physicians of India, 60, 26-28.

[34] Duleba, K., Pawłowska, M. and Wietlicka-Piszcz, M. (2014) Clostridium difficile Infection in Children Hospitalized Due to Diarrhea. European Journal of Clinical Microbiology \& Infectious Diseases, 33, 201-209.

https://doi.org/10.1007/s10096-013-1946-1

[35] Talpaert, M.J., Gopal Rao, G., Cooper, B.S. and Wade, P. (2011) Impact of Guidelines and Enhanced Antibiotic Stewardship on reducing Broad-Spectrum Antibiotic Usage and Its Effect on Incidence of Clostridium difficile Infection. Journal of Antimicrobial Chemotherapy, 66, 2168-2174. https://doi.org/10.1093/jac/dkr253

[36] Crews, J.D., Anderson, L.R., Waller, D.K., Swartz, M.D., DuPont, H.L. and Starke, J.R. (2015) Risk Factors for Community-Associated Clostridium difficile-Associated Diarrhea in Children. Pediatric Infectious Disease Journal, 34, 919-923. https://doi.org/10.1097/INF.0000000000000767

[37] Balassiano, I.T., Yates, E.A., Domingues, R.M. and Ferreira, E.O. (2012) Clostridium difficile: A Problem of Concern in Developed Countries and Still a Mystery in Latin America. Journal of Medical Microbiology, 61, 169-179. https://doi.org/10.1099/jmm.0.037077-0

[38] Aldeyab, M.A., Kearney, M.P., Scott, M.G., Aldiab, M.A., Alahmadi, Y.M., Darwish Elhajji, F.W., Magee, F.A. and McElnay, J.C. (2012) An Evaluation of the Impact of Antibiotic Stewardship on Reducing the Use of High-Risk Antibiotics and Its Effect on the Incidence of Clostridium difficile Infection in Hospital Settings. Journal of Antimicrobial Chemotherapy, 67, 2988-2996. https://doi.org/10.1093/jac/dks330 